\title{
A Qualitative Study to Assess Nurses' Concern Regarding Impacting Factors on Clean \& Healthy Practice in a Tertiary Level Hospital UP, India
}

\author{
Maj Sivapriya ${ }^{1}$, Lt Col Rekha Bhattacharya ${ }^{2}$ \\ ${ }^{1}$ Clinical Tutor, College of Nursing, Command Hospital (CC), Lucknow, Uttar Pradesh, India \\ ${ }^{2}$ Professor, College of Nursing, Command Hospital (CC) Lucknow, Uttar Pradesh, India
}

\begin{abstract}
Introduction: Nurses are a part of Swachh Bharat Abhiyaan campaign and aims to accomplish the vision of a 'Clean India' by 2 October 2019. Health care acquired infections (HCAI) are a common complication that affects hospital treated patients because of poor basic hygiene practices. The occurrence of HCAI is a big problem in India, mostly because of a low compliance to the healthy behaviours and hygiene practice. The nurses have an important role in this campaign by informing and motivating the staff to keep a good compliance to healthy and hygiene practice. Aim - To assess nurses' concern regarding impacting factors on clean and healthy practice in a tertiary level hospital Uttar Pradesh, India. Method - Data was gathered through qualitative interviews. Data Analysis - The interviews were tape recorded, transcribed and then analysed through content analysis. Results - Four main categories was identified as important for conducting a successful clean and healthy practice; Routine activities carried out in clinical field, existing opportunities in clinical field to conduct a clean and healthy India practice, various areas to be focused and the obstacles to conduct a successful campaign.
\end{abstract}

Keywords: nurses' concern, clean \& healthy India

\section{Introduction}

India is a developing multicultural country, with a population of 1.252 billion inhabitants, a steadily growing number. The total expenditure on health care every year goes up to 3.9 percent of gross domestic product (GDP) and the number of hospital beds per 1000 inhabitants are 0.9 (WHO 2014). The quality of health care in India is varying and there is a massive lack of medical staff (Tiwari 2013; Wennerholm 2013). The occurrence of Health Care Acquired Infections (HCAI) is a big problem in India, mostly because of a low compliance to clean and healthy practice among health care staff, patients and relatives (Mathai et al. 2011). Mathai et al. (2011) investigated hand hygiene compliance rates among staff in an intensive care unit in India. They could conclude that through multi-modal interventional strategies such as visible reminders and easily accessible hand hygiene products compliance could be distinctly improved.

Swachh Bharat Abhiyan (Hindi: स्वच्छ भारत अभियान, English: Clean India Mission) is a national campaign by the Government of India, covering 4041 statutory towns, to clean the streets, roads and infrastructure of the country. This campaign was officially launched on 2 October 2014 at Rajghat, New Delhi, where Prime Minister Narendra Modi himself cleaned the road. It is India's biggest ever cleanliness drive and 3 million government employees including nursing staff and students of India participated in this event. It has been carried forward since then with people from all walks of life joining it. This campaign aims to accomplish the vision of a 'Clean India' by 2 October 2019, the 150th birthday of Mahatma Gandhi. Nurses have a vital role in achieving some Specific objectives of this campaign are:
- $100 \%$ collection and scientific processing/disposal/reuse/recycling of waste

- A behavioural change in people regarding healthy sanitation practices

- Generation of awareness among citizens about sanitation and its linkages with public health

\section{Scope of the Study}

Infections are an important global health problem because they occur frequently, cause morbidity and mortality and represent a significant burden among patients, health care workers and health systems. It has been known for a long time that basic hygiene is of importance when it comes to prevent any sort of infection. Regardless of this the compliance still remains low in many parts of the world. This is a problem also in India where health care is lacking in many ways. Nurses have an important role when it comes to working preventive against HCAI. Therefore it is of interest to illuminate nurses' experiences of impacting factors on clean and healthy practices.

\section{Aim}

To assess nurses' concern regarding impacting factors on clean and healthy practice in a tertiary level hospital Uttar Pradesh, India.

\section{Objectives}

i. To assess the relevance of theme: "Clean \& healthy India: Nurse's concern" in current scenario

ii. To assess the various routine activities carried out by nurses in their clinical field to promote clean and healthy India.

iii. To explore the opportunities existing in clinical field to conduct a successful clean and healthy practice 


\section{International Journal of Science and Research (IJSR) \\ ISSN (Online): 2319-7064 \\ Index Copernicus Value (2013): 6.14 | Impact Factor (2015): 6.391}

iv. To analyze the areas to be improved in order to improve the infection control in nursing care and work for clean \& healthy India

v. To explore the obstacles that nurses felt exist at clinical fields that can have impact on the opportunity to conduct a successful clean \& healthy practice.

\section{Research Methodology}

\section{Research Approach}

A qualitative approach was selected considering it as the most appropriate in view of the nature of the problem and accomplishes the objectives of the study.

\section{Sampling}

Purposive sampling method was selected because the more experienced nurses can give valuable suggestions on this theme. Investigator preferred to include nursing officers with administrative and clinical experience as samples.

\section{Inclusion Criteria}

Registered nurses with minimum 10 years of experience

\section{Sample Size}

Sample size was limited to 20 as it is a qualitative study conducted using interview schedule as tool for data collection.

\section{Tool Preparation}

\section{Section I}

Sample distribution as per demographic and baseline variables $\mathbf{n}=\mathbf{2 0}$
As the purpose of this study was to collect the information and opinion regarding clean and healthy India, investigator selected interview schedule as the best method giving opportunity for the participants to express their views openly.

Section I: Selected demographic and baseline data Section II: Interview guide on various aspects of clean and healthy practices

\section{Data Collection}

A group of possible participants were identified by the researcher. A brief description was given to all participants regarding study and purpose of this study. Those who then volunteered to participate were included in the study and got further oral and written information when meeting for the interview.

This study was approved by the ethical committee of selected tertiary level hospital.

\section{Analysis, Interpretation, Discussion}

Scheme of statistical analysis was following:

- Section I: The demographic and baseline data in relation to age, education, present designation, years of experience and experience in other fields than nursing.

- Section II: Categories \& subcategories regarding clean \& healthy India concern

\begin{tabular}{|c|c|c|c|}
\hline \multicolumn{2}{|c|}{ Parameters } & No of Nursing staff & Percentage \\
\hline \multirow{3}{*}{ Age (Yrs) } & $30-40$ & 5 & 25 \\
& $40-50$ & 10 & 50 \\
\hline \multirow{2}{*}{ Educational } & $50-60$ & 5 & 5 \\
qualification & B Sc Nsg & 1 & 45 \\
& PB BSc Nsg & 9 & 50 \\
\hline \multirow{3}{*}{ Years of experience } & M Sc Nsg & 10 & 25 \\
& $10-15$ & 5 & 50 \\
\hline
\end{tabular}

No participants had experience any other field than nursing 


\section{International Journal of Science and Research (IJSR) \\ ISSN (Online): 2319-7064}

Index Copernicus Value (2013): 6.14 | Impact Factor (2015): 6.391

\section{Section II}

Categories \& subcategories regarding clean \& healthy India Nurses: Concern

\begin{tabular}{|l|l|}
\hline \multicolumn{1}{|c|}{ Category } & \multicolumn{1}{c|}{ Sub-Category } \\
\hline Relevance of the theme & $\begin{array}{l}\text { Swachh Bharat abhiyaan } \\
\text { Primary prevention }\end{array}$ \\
\hline Routine activities carried out in clinical field & $\begin{array}{l}\text { Hand washing } \\
\text { Aseptic principles during all procedures } \\
\text { Proper biomedical disposal } \\
\text { Regular culture report of surface, equipments and air } \\
\text { Dusting, cleaning, washing and maintenance of surrounding area }\end{array}$ \\
\hline $\begin{array}{l}\text { Opportunities existing in clinical field to } \\
\text { conduct a clean and healthy practice }\end{array}$ & Hospital infection control committee \\
\hline & $\begin{array}{l}\text { Regular hand washing practices by nurses } \\
\text { Recruitment of more housekeeping staff } \\
\text { Areas to be considered in order to improve the } \\
\text { infection control in nursing care and work for } \\
\text { clean and healthy India }\end{array}$ \\
$\begin{array}{l}\text { Retrospective/prospective studies to assess the survival rate, duration of stay and infection } \\
\text { control } \\
\text { In service education and community outreach programmes } \\
\text { Practice of Swachh Bharat abhiyan at least once in a month in collaboration with staff, } \\
\text { patients and community. } \\
\text { Nutrition \& healthy living exhibitions for the public in OPDs and public places } \\
\text { Regular health camps and awareness programmes }\end{array}$ \\
\hline $\begin{array}{l}\text { Obstacles nurses felt at their clinical field that } \\
\text { can have an impact on the opportunity to } \\
\text { conduct a successful clean and healthy practice }\end{array}$ & $\begin{array}{l}\text { No standard training for housekeeping staffs } \\
\text { Inadequate staffing pattern } \\
\text { No motivation or appraisals from administration } \\
\text { Inadequate resources such as cleaning materials, water supply, dust bins } \\
\text { Toilet facilities near OPDs and public places. }\end{array}$ \\
\hline
\end{tabular}

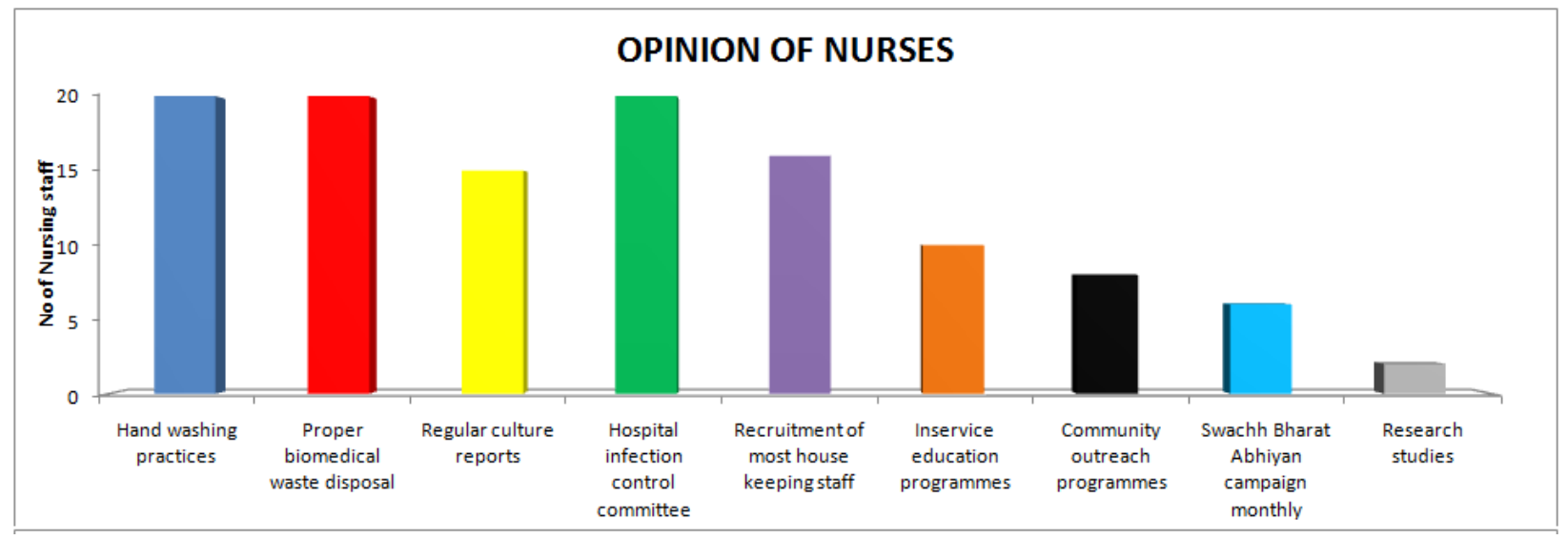

The nurses expressed that knowledge of infection transmission among staff as well as common people is important in clean and healthy practice. Their responses centred around three areas to improve clean and healthy practices which were inculcate primary prevention and Swachh Bharat Abhiyaan among all health care staff, hospital infection control committee, routine activities for the maintenance of clinical field and environment, adequate infrastructure and material supply, in-service education programmes for health care staff, counselling and health education programmes in hospital settings and community outreach programmes.

\section{Discussion}

One of the main things that could be identified as important to accomplish a successful hygiene practice was knowledge. This included having educated staff, maintaining aseptic conditions and that patients and relatives were aware of HCAI and how they transmit. Abela and Borg (2012) mean that informational posters at the wards did not increase compliance to hygiene routines. The nurses in this study talked about this and meant that compliance to hygiene routines was low at their hospital because of a lack of knowledge among staff. According to Abela \& Borg (2012) posters had to be combined with educational sessions for the staff to impact positively on the compliance to hygiene routines. Skår (2009) mean that the use of experienced nurses' knowledge in everyday nursing practice contributes significantly to the quality of health care. Another area that the interviewed nurses considered important were administrative support and that there is a need of infection control committee. Takahashi and Turale (2010) point out the need for nurses who are specialized in health-care hygiene who can translate theory into practice and be a leader for the rest of the staff in the daily work with the patients. This motivates the healthcare personnel to maintain the hygiene routines. When 


\section{International Journal of Science and Research (IJSR) \\ ISSN (Online): 2319-7064 \\ Index Copernicus Value (2013): 6.14 | Impact Factor (2015): 6.391}

there are skilled and dedicated nurses in hygiene practice who participate in the nursing care of the patients, this affects the compliance to hygiene routines among the other staff at the ward in a positive way (Lind et al. 2013; Bamford et al. 2013; Akyol 2005). The nurses talked about the importance of having enough material and financial resources. The availability of resources and material has a direct influence on the compliance to hygiene routines, easily accessible material contributes to a higher compliance among health care workers and the other way around (Sax et al. 2007; Lindh et al. 2013; Akyol 2005). The nurses in this study expressed that sometimes material was not available at the wards, even though the knowledge and will to use it existed. According to Mills (2011) having knowledge is not always enough; financial resources often have a great impact on what material is available. This is a big problem especially in low-income countries where the financial resources to invest in health care is not always present (Mills 2011).

A variety of factors have an impact on clean and healthy practices. A nurse have adequate knowledge level but is important having enough staff, sufficient material and facilities in order to bring clean and healthy India into practice.

\section{References}

[1] Abela, N. \& Borg, M.A. (2012). Impact on hand hygiene compliance following migration to a new hospital with improved resources and the sequential introduction of World Health Organization recommendation. American journal of infection control, 40, 737-41.

[2] Akyol, A.D. (2005). Hand hygiene among nurses in Turkey: opinions and practices. Journal of Clinical Nursing, 16, 431-437.

[3] Ashraf, M.S., Hussain, S.W., Agarwal, N., Ashraf, S., El-Kass, G., Hussain, R., Nemat, H., Haller, N., Pekmezaris, R., Sison, C., Walia, R., Eichrorn, A., Cal, C., Dlugacz, Y., Edwards, B.T., Louis, B., Alano, G. \& Wolf-Klein, G. (2010). Hand hygiene in longterm care facilities: a multicenter study of knowledge, attitudes, practices and barriers. Infection control and hospital epidemiology, 31 (7), 758-762

[4] Bamford, M., Wong, C.A. \& Laschinger, H. (2013). The influence of authentic leadership and areas of worklife on work engagement of registered nurses. Journal of nursing management, 21 (3), 529-540.

[5] Benner, P. (1993). Från novis till expert - mästerskap och talang i omvårdnadsarbetet. Lund: Studentlitteratur.

[6] Björling, E., Matiasson, A. (2008) Sjuksköterskans ledarskap i teamet - möjligheter och hinder för sjuksköterskan att arbeta i team. Göteborg: Göteborgs universitet.

[7] CODEX. (2013). Informerat Samtycke. [Elektronic] Available: http://www.codex.uu.se/manniska2.shtml [2014-03-13].

[8] Elg, M. \& Olsson, J. (2013). Organisera för ständiga förbättringar i hälso- och sjukvården. I Leksell, J. \& Lepp, M. (red.) Sjuksköterskans kärnkompetenser. Stockholm: Liber.
[9] Emori, TE. \& Gaynes, RP. (1993). An overview of nosocomial infections, including the role of the microbiology laboratory. Clinical Microbiology Reviews, 428-442.

[10] Familypedia (2014). Wardha district. [Electronic]. Available: http://familypedia.wikia.com/wiki/Wardha_district [2014-03-13] 